\title{
FAMILY TRADITIONALISM AND AGE-SPECIFIC NUPTIALITY PATTERNS: WHAT DOES THE EXAMPLE OF KARACHAY-CHERKESSIA POINT TO?
}

\section{KONSTANTIN KAZENIN}

\begin{abstract}
The paper deals with the relation between traditional family norms and women's age at first marriage. The study is based on data from Karachay-Cherkessia, a republic of the North Caucasus (Russia), and uses results of a survey among women of reproductive ages conducted there in 2018. It has been demonstrated that traditional family norms, including those empowering elder generations and limiting women's social role to housework and bringing up children, are rather strong in that region. It is currently assumed that these norms generally correlate with women's younger age at first marriage. However, our analysis of the data from Karachay-Cherkessia, which used proportional hazard models and logistic regressions, does not fit this assumption. Specifically, it turns out that precisely that ethnic group of Karachay-Cherkessia which shows a higher concentration of traditional family norms also demonstrates a statistically significant tendency towards women's older age at first marriage. Thus the relation between traditional family norms and the timing of marriage appears to vary more across different societies than is supposed. The consequences of this result for the study of demographic transformations taking place in different countries and regions together with the breakdown of traditional family norms are discussed.
\end{abstract}

Key words: North Caucasus, nuptiality, age at marriage, traditional family norms, gender asymmetries.

\section{INTRODUCTION}

The article is devoted to the relationship between the characteristics of the family structure and the age parameters of demographic events. We focus on those characteristics of the family structure which are usually assumed under the concept of "traditional family", meaning, first of all, family norms that reinforce the authority of the older generation over the younger and limit the woman's role to raising children and to housework. A common belief among researchers is that the more "traditional" in this sense the family structure in a society is, the lower will be the age at which a woman marries, the age at birth of her first child, etc. This view is confirmed by data from numerous countries, most of them outside Western Europe and North America (see section 3).

Based on data from a quantitative field study conducted in one of the regions of the North Caucasus (Karachay-Cherkessia - KCR), the article shows that such a pattern is not, however, necessary. We focus on the influence of "traditionalism" in the family structure on the age at which a woman marries. Analysis shows that the situation in the region we are studying is in many ways the opposite of typical expectations: the indigenous peoples of Karachay-Cherkessia differ in age models of marriage, but an older age of marriage for a woman is characteristic of precisely that ethnic group (the Karachais) which today has more norms of the traditional way of life.

Konstantin Kazenin (kz@ranepa.ru), The Russian Presidential ACADEMy of National Economy AND Public ADMINISTRATION, RUSSIA.

THE ORIGINAL ARTICLE IN RUSSIAN WAS PUBLISHED IN DEMOGRAPHIC REVIEW 2019. 6(3): 98-127.

DOI: 10.17323/DEMREVIEW.V6I3.9857 
The preservation of the norms of a traditional family implies adherence to certain age standards of marriage, but these standards may be different for different peoples even within the same region and do not necessarily imply an early age of marriage for a woman. Such a complication of existing ideas about the relationship between family "traditionalism" and the agerelated characteristics of marital and reproductive behavior has important consequences for the analysis of the demographic transformations that are occurring today in various societies with a breakdown of the traditional family structure.

The article is structured as follows. Section 2 briefly introduces the concept of traditional family norms with which we operate during the study. Section 3 discusses the current understanding of the relationship between traditional family norms and the parameters of matrimonial and reproductive behavior. Section 4 is devoted to the general demographic characteristics of Karachay-Cherkessia. Section 5 describes the quantitative survey that formed the basis of our study and presents some of its descriptive results. Section 6 is devoted to a statistical analysis of factors affecting the age of marriage of a woman (based on survey data). Section 7 discusses the results of the analysis.

\section{THE TRADITIONAL FAMILY APPROACH: THE CONCEPT AND MEASUREMENT METHODS}

The concept of the traditional family structure used in this work is connected with the conceptual apparatus developed by the founder of the distinction between modern and traditional societies, the German sociologist F. Tönnis, who contrasted the Gemeinschaft, a community, with the Gesellschaft, a society of the modern type (Tönnis 2002). Among the basic features of the Gemeinschaft, according to Tönnis, is the presence in a family of strict gender and generational asymmetries, as well as an individual's great dependence on the family and the community. This can take the form of a strict distinction between the functional roles of spouses in the family, of the dependence of young people on older relatives when making important life decisions, and on close ties between relatives within the framework of an "extended family".

Numerous works have shown that the above-listed characteristics of the Gemeinschaft are to a large extent characteristic of today's North Caucasus (Pavlova 2012; 2013; Sabanchieva 2016; Molodikova, Watt 2014). It should be noted at the same time that the available research also reveals noticeable differences between different North Caucasian territories and ethnic groups in terms of the degree to which the traditional way of life of the family is preserved, in how much it has undergone erosion due to the social transformations of Soviet and post-Soviet times. (See, for example, (Karpov 2001) regarding such differences in the position and social role of women, and (Starodubrovskaya 2019) on the transformation of the system of generational and gender relations in some North Caucasian communities.) Researchers generally agree that the changes that took place in the North Caucasus in the last third of the 20th and the beginning of the 21st centuries, primarily the massive relocation of the local population to cities, have largely affected the family structure and, to one degree or another, caused its "modernization." However, this has not led to a leveling of differences between the North Caucasus and most other parts of Russia. Therefore, the question of the influence of the traditional family structure on the demographic behavior of the population, including matrimonial behavior, remains relevant for the modern North Caucasus. 
The literature offers a large number of parameters by which the degree of rigidity of gender and generational hierarchies in a given society can be estimated. Various parameters related to the presence of gender hierarchies are systematically reviewed in (Mason 1987; Morgan et al. 2002; Agarwala, Lynch 2006). Almost all the parameters discussed there relate to the restrictions imposed on the role of women in the family and on the freedom of women to make certain decisions. Obviously, in the study of any particular society, some of the proposed parameters may be more, and some less applicable. Some of the parameters discussed in these works, relevant for other regions of the world, are hardly relevant for today's realities of the North Caucasus (for example, the maximum distance of a day trip that a woman can make alone; such severe restrictions, according to our field observations, are generally not characteristic of today's North Caucasus). On the other hand, a large number of parameters proposed in the literature relate to various aspects of relations within a married couple, primarily the opportunity for a wife to take various actions without the approval of her husband (from making large purchases to visiting her relatives). Our fieldwork experience shows that women respondents are unlikely to agree to answer questions about various aspects of their relationship with their spouses in many North Caucasian communities. Therefore, we limited the study of gender asymmetries to the most "objective" parameters relating to those aspects of a woman's life that are visible to others and about which she is unlikely to have difficulties reporting to the interviewer. Thus, for the study of gender asymmetries in the framework of a quantitative survey of women, we use the following parameters:

- the fact that a woman has received an education higher than that required by law;

- the existence of a woman's labor activity outside the household.

- a woman's contribution to family income.

These parameters show whether the role of the wife and mother is exclusively assigned to the woman in the family and to what extent the woman has the opportunity to go beyond this role. As for generational asymmetries, the parameters by which they can be detected relate to the freedom of the younger generation to make certain life decisions, regardless of the opinions of older relatives. We use three groups of such parameters.

First come parameters reflecting the role of the woman's elder relatives at the time of her marriage. Marriage on the initiative and with an active organizing role of elder relatives of the bride and groom (arranged marriage) is considered in the literature as one of the manifestations of generational asymmetries in family relationships and, in general, as an important component of family "traditionalism" (Ahearn 2001: 76, Collier 1997). At the same time, anthropological studies in different regions of the world have shown that the actual role of older relatives in marriage can be different, and that the binary contrast between a marriage organized by older relatives and a marriage concluded by future spouses without the participation of elders is not adequate (Hart 2007). With this in mind, as well as relying on the results of our qualitative field studies (in-depth semi-structured interviews) among residents of the North Caucasus, we consider the following parameters regarding the role of older relatives in marriage: 1) whether the future spouses met at the initiative of older relatives or independently; 2) whether the marriage was on the advice of older relatives or on the initiative of the future spouses (taking into account the variability of "marriage scenarios" actually witnessed in the North Caucasus, an "interim" alternative is also allowed, which corresponds to the answer option "they made the decision on marriage themselves, 
but on the advice of the older relatives"); 3) whether at least one of the wife's parents originates from the same village as at least one of the husband's parents. All of the above parameters, of course, are determined only for women who are married or have been married (if a woman has married more than once, the questions in the questionnaire of our study concerned her first marriage).

Secondly, to assess the effectiveness of intergenerational asymmetries in a woman's family, we use parameters characterizing the opportunity for a woman to make various life decisions without receiving the approval of older relatives. Such decisions include the decision to apply for a job, to study and to change jobs, the decision to move for permanent or temporary residence in another region, the decision to change the place of residence within the same location and some others. A preliminary estimate using such criteria suggests that in today's North Caucasus significant diversity should be expected both between regions and between districts, ethnic groups, and even individual locations within regions (Kazenin, Kozlov 2017b). All these features are definable for adult women regardless of their marital status. Note that in the literature, the opportunity for a woman to make independent decisions on such issues is more often considered as a characteristic of her relationship with her spouse, i.e., of gender asymmetries in the family (Morgan et al. 2002). We explained above the decision not to use such parameters as indicators of gender asymmetries in our study, but we believe it is possible to use them to study generational asymmetries, focusing on the independence of women in these matters not from her husband, but from older family members.

Finally, as another "measure" of generational asymmetries, we use the parameter of living jointly with or separately from older relatives. The predominance of an "extended" family, including several generations of adults, with young families living together with their husbands' relatives is considered a key feature of "patriarchy", a concept actively used in one of the schools of modern research on family transformation (Kaser 2002; Gruber, Szołtysek 2012; Lerch 2013). The difference between the concept of "patriarchy" in these works and the concept of a traditional family described above consists mainly in the fact that "patriarchy" is determined not so much by the system of relations in the family as by the composition of households. We find it possible to consider the parameters of "patriarchy" along with other characteristics of the family structure that we use.

\section{3. “TRADITIONALITY” OF THE FAMILY AND MARITAL AND REPRODUCTIVE BEHAVIOR}

Existing studies of the relationship between the characteristics of the family structure that characterize it as traditional and the parameters of marital and reproductive behavior outside Western Europe and North America almost unanimously lead to the following conclusion: the more "traditional" the family structure, the higher the fertility and the lower the age at which a woman gets married and has her first child ${ }^{1}$. So, in (Malhotra, Vannemann, Kisher 1995) it is

\footnotetext{
${ }^{1}$ The reservation concerning the countries of Western Europe and North America is related to the asymmetry well known in world demography, usually called the Hajnal line (see: Hajnal 1979) and dividing European countries along the line St. Petersburg - Trieste . As was originally shown in (Hajnal 1965), relatively late marriages with a 
shown that in those areas of India where available social statistics indicate a high degree of discrimination against women, fertility is higher than in other areas of the country. Similar conclusions are made for Albania in (Lerch 2013), where fertility is also examined in a territorial context. In (Morgan et al. 2002) a similar relationship between various parameters of the "traditional" family structure is argued for on the example of different communities in Southeast Asia.

Along with fertility, a number of works have also demonstrated a link between the age characteristics of marital and reproductive behavior, especially a woman's age at marriage, and the strength of gender and generational hierarchies in a woman's family. A well-known study (Dyson, Moore 1983) showed that those states of India where there is more severe gender discrimination are characterized by a younger age for women to marry. In (Gruber, Szołtysek 2012), the younger age of a woman at marriage is also considered as one of the correlates of the "patriarchal" family structure.

Studies of some post-Soviet countries and regions showed, based on sample surveys, that the factor "supporting" the birth rate there in the first decades after the collapse of the USSR was a partial renaissance of family "traditionalism," primarily a sharp contrast of gender roles and/or the authority of older generations in the family (see, e.g., (Dommaraju, Agadjanian 2008) for some countries of Central Asia). In (Kazenin, Kozlov 2017a), it was shown that a number of characteristics of the "traditional" family structure, along with a woman's personal religiosity, correlate with a mother's younger age at the birth of her first child in Dagestan.

\section{KARACHAY-CHERKESSIA: SOME DEMOGRAPHIC FEATURES}

Karachay-Cherkessia (KCR) is a republic in the western part of the North Caucasus. Its population, according to Rosstat, came to 466,305 people as of January 1, 2018. The shares of the most populous peoples in the republic's population, according to the 2010 All-Russian Population Census (VPN), were: Karachais - 41.0\%, Russians - 31.6\%, Circassians - 11.9\%, Abazins - 7.8\%, Nogais $-3.3 \%$. The republic is characterized by a very low share of the urban population compared with the Russian Federation as a whole: as of January 1, 2018, city-dwellers made up $42.7 \%$ of all residents of the republic. As shown in (Belozerov 2005), the most noticeable increase in the urban population in the region took place in the 1960s and 1970s, primarily due to the migration of the rural population to cities. The percentage of the urban population according to the 1959 All-Union Population Census was only $23.6 \%$, while according to the 1979 census it was already $43.5 \%$, i.e., close to today's level. In the 1960s and 1970s it was the Russian population which prevailed among

high proportion of never married by the end of reproductive age historically predominated to the left of this line, and early marriages with a low proportion of never married historically prevailed to the right of it. The two historical types of marriage identified by J. Hajnal were called respectively "Western European" and "Eastern European." It is significant that Hajnal pointed to the great "age" of this opposition, to its existence even before the large-scale social changes that took place in Western Europe in modern times. Thus, for the countries of Western Europe, the marriage model of which was largely reproduced by the population of West European descent in North America, the late age of marriage of women can be considered as an element of the traditional family life. However, for other continents, this possibility is practically not considered in the literature. 
migrants from the village to the city, but afterwards there was an intensification of the migration to the cities of local ethnic groups along with the departure of part of the Russian urban population to other regions (Belozerov 2005: 108-130). This was reflected in the share of "autochthonous" ethnic groups among the residents of the capital of the Republic of Cherkessk (where in $201861 \%$ of the total urban population of the republic and $26 \%$ of all residents of the region are concentrated): according to census data, in 1959 the total share in the city of the four most numerous non-Slavic peoples of the region (Karachais, Circassians, Abazins, Nogais) came to $5.9 \%$, in $1970-11.9 \%$, in $1979-18.6 \%$, in $1989-24.5 \%$, in $2002-36 \%$ and in $2010-39.3 \%$.

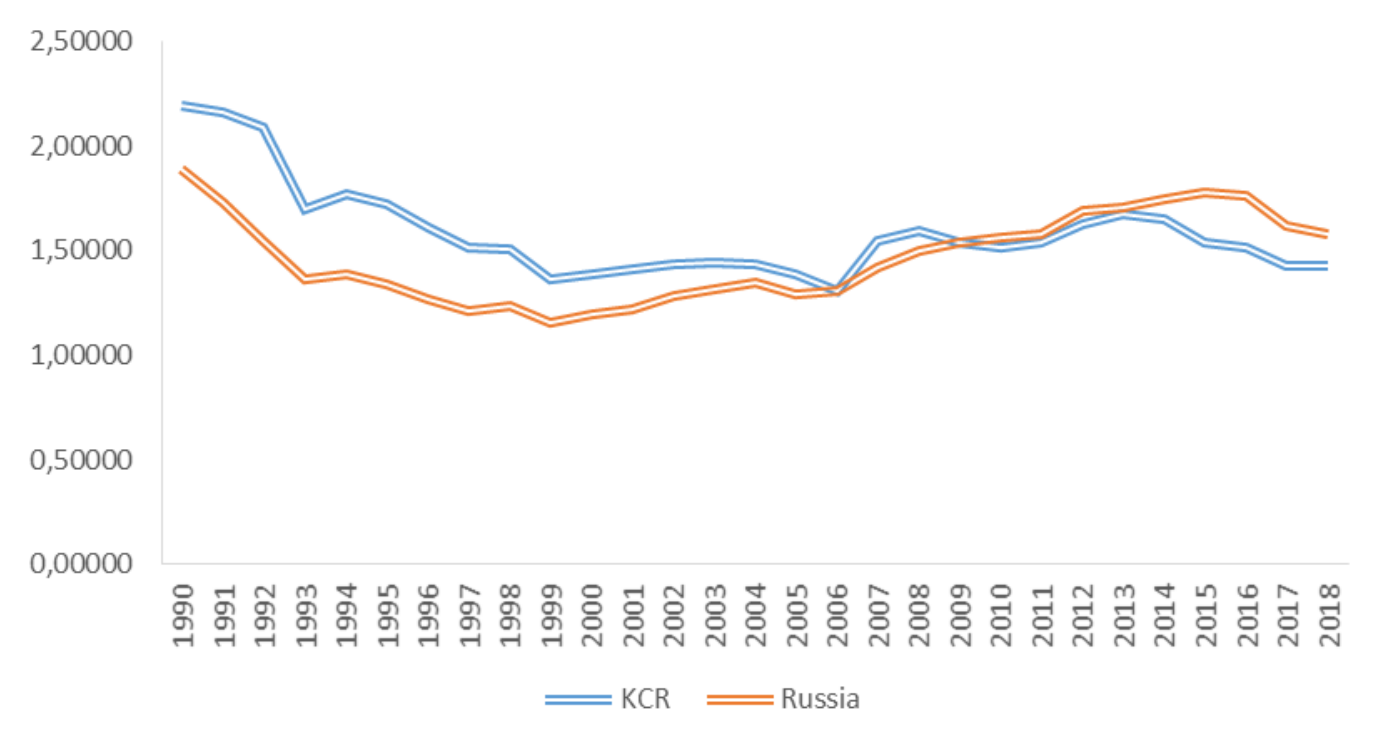

Figure 1. Total fertility rate, Russia and KCR, 1990-2018

Source: Rosstat data.

The region's fertility dynamics after the collapse of the USSR, according to official statistics, generally repeated the all-Russian one, declining in the 1990s and gradually recovering in the 2000s (Figure 1). The absolute value of the total fertility rate (TFR) from 1990 to 1999 in the KCR exceeded the national average by 25\%; later the difference between the region and the country significantly decreased. The higher fertility in comparison with the rest of Russia in the 1990s can be explained, in particular, by the fact that among the non-Slavic peoples of the region the decline in fertility corresponding to the first demographic transition took place later than that among ethnic Russians. As shown in Figure 2, according to the 2010 census, among Karachais, Circassians, Abazins, and Nogais over the age of 40-44, the number of children born per 1,000 women exceeded 2,000, while among the region's Russian population the figure was below 2,000 in all age groups under 70 years old. Fertility among non-Slavic ethnic groups, as can be seen in Figure 2, was higher than among Russians also for those age groups that were of reproductive age in the 1990s. However, in the age groups younger than 30 years, the 2010 census no longer recorded the Russians' lag behind non-Slavic ethnic groups in accumulated fertility: Figure 2 shows a significant interethnic convergence in birth rates at these ages. That is, the KCR's lag behind the Russian Federation as a whole in terms of fertility, which began after 2009, continued under conditions when the ethnic composition of the region ceased to be a factor contributing to a higher level in the KSR compared to the country as a whole. It is interesting to note that the high proportion of the rural population in the KCR also did not lead to a higher fertility rate in the 2000- 
2010s compared to the all-Russian one. The increase in the share of non-Slavic indigenous ethnic groups in the population of the republic, caused by the departure of the Russian population from the KCR, did not lead to it either ${ }^{2}$.

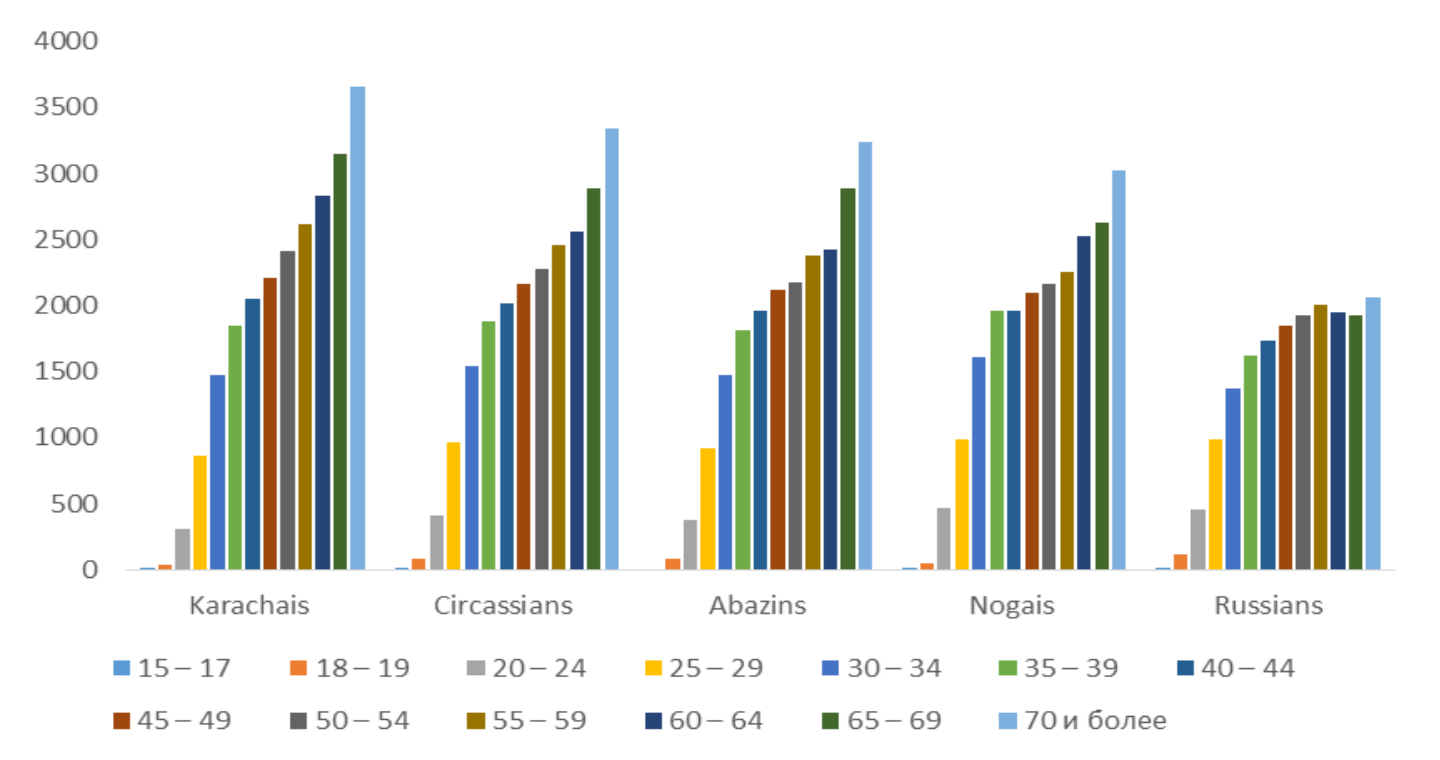

Figure 2. The number of children born per 1000 women in the main nationalities of the KCR by age group, 2010

Source: VPN-2010 data.

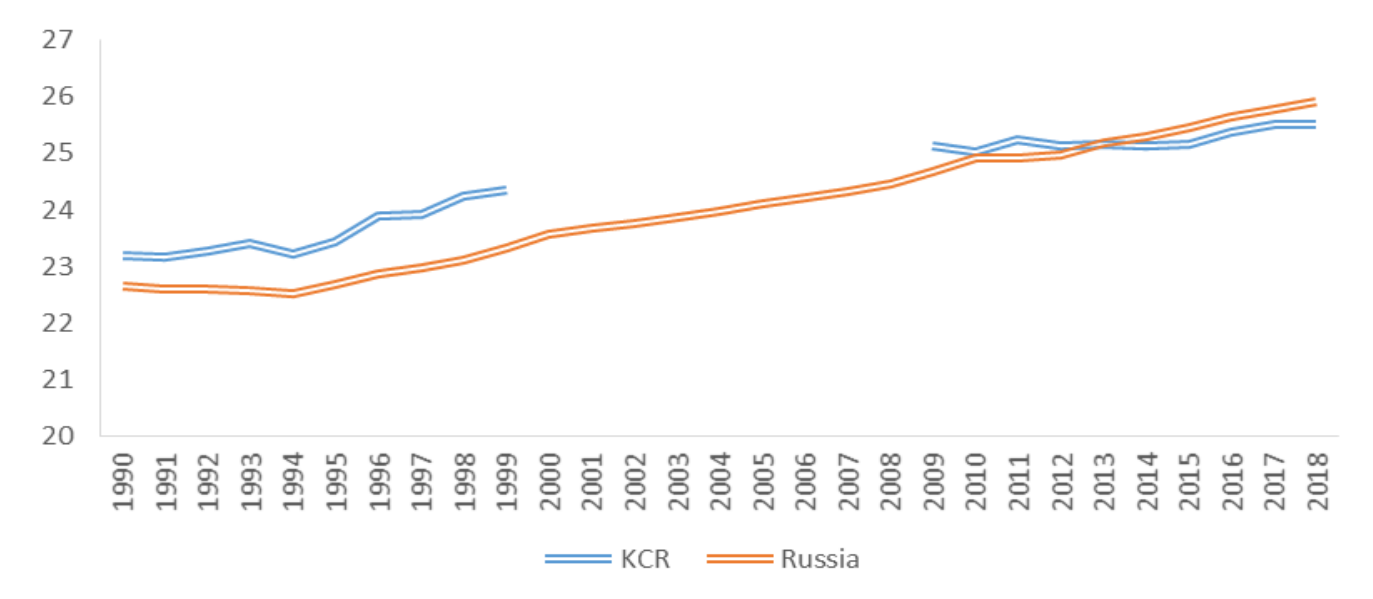

Figure 3. The average age of the mother at the birth of the first child, RF and KCR, 1990-2018

Source: Rosstat data.

\begin{abstract}
${ }^{2}$ A.I. Raksha drew the author's attention to the fact that the low values of the TFR for the KCR in the 2010s can be associated with overstated data on the number of women in reproductive ages. The possibility that the low fertility recorded by official sources in the region during this period may partly be an "artifact" of population counting is hinted at by the extraordinarily low TFR value for first children: according to Rosstat, in 2015 this indicator in the KCR came to only 0.53 , in $2016-0.51$, in $2017-0.48$; these values are almost a third lower than the national figures for the same years. Such a low fertility rate of first children could be explained by the mass postponement of first births, but the dynamics of the average age of the mother reflected in the data of the Federal State Statistics Service at the birth of the first child in the KCR for 2015-2017 do not indicate this (Figure 3).
\end{abstract}


From the age-related characteristics of fertility we consider the dynamics of the mother's age at the birth of the first child in the KCR compared with the national one (Figure 3; data on the KCR are not available for 2000-2008, when statistics on order of births were not developed in the region). The age of the "start" of motherhood at the time of the collapse of the USSR in the KCR was slightly higher than in the Russian Federation as a whole, and then it mainly grew, but more slowly than the national indicator, and in recent years has even fallen somewhat behind it.

\section{QUANTITATIVE RESEARCH IN THE KCR: CHARACTERISTICS AND SOME DESCRIPTIVE RESULTS}

A survey of women aged 15-39 was conducted in May-June 2018 in all urban districts and municipal districts of Karachay-Cherkessia (there are two urban districts in the republic Cherkessky and Karachayevsky - and ten municipal districts). A total of 756 women were interviewed. The survey was conducted by going around households with local female interviewers who had received the necessary training, followed by telephone control.

The number of respondents in each district or urban district was proportional to the share of its inhabitants in the total number of residents of the KCR (in the absence of official data on the current age and sex structure by municipalities, it was not possible to take into account only the share of women included in the age survey in their total number in the KCR). In each municipal district, the settlements were divided into two groups according to the number of inhabitants ("large" and "small" villages), and from each such group in each district two villages were randomly selected for the survey. In urban districts, four neighborhoods were randomly selected for the survey. In each household no more than one respondent was interviewed. Quotas according to age groups within villages and towns were not used. This was due to the already mentioned lack of relevant official data on the gender-age and ethnic structure of the population for the municipalities of the KCR which could serve as the basis for such quotas. Table 1 shows the distribution of respondents by five-year age groups in comparison with the Rosstat data on the share of these age groups among all women age 15-39 in the KCR on January 1, 2017².

Table 1. Distribution of respondents by age group

\begin{tabular}{l|c|c|c}
\hline & Number & $\%$ & $\begin{array}{c}\text { The share of this age group among all women age 15- } \\
\text { 39 in the KCR as of January 1, 2017 (Rosstat).\% }\end{array}$ \\
\hline $15-19$ & 153 & 20.2 & 14.9 \\
$20-24$ & 164 & 21.7 & 16.8 \\
$25-29$ & 161 & 21.3 & 23.6 \\
$30-34$ & 144 & 19.0 & 23.9 \\
$35-39$ & 134 & 17.7 & 20.8 \\
Total & 756 & 100.0 & 100.0 \\
\hline
\end{tabular}

As one can see, in our survey there was a higher, compared with official statistics, percentage of respondents of young ages, for which there could be at least two reasons. Firstly, a

\footnotetext{
${ }^{3}$ Unfortunately, a number of problems in registering refusals to participate in the survey during the study make it impossible to accurately determine the number of respondents who did not agree to the proposal to answer the questionnaire. One can, however, speak of a higher percentage of failures in cities than in rural areas. Among cities, the highest failure rate was observed in Cherkessk.
} 
"bias" towards young ages could arise due to the large proportion of respondents in Cherkessk among all respondents in our sample (this large proportion was, in turn, due to the high share of the population of Cherkessk among the inhabitants of the region; see above). In Cherkessk, the concentration of young people is higher due to greater educational and job opportunities compared to rural areas and the town of Karachayevsk. Secondly, the proportion of women over 30 among the respondents could be less than indicated by official statistics due to the significant prevalence of labor migration of women of these ages outside the region.

In the distribution of respondents by ethnicities, a higher proportion of Karachais and a lower proportion of Russians compared to the percentage of these peoples among women aged 1539 years according to the 2010 All-Russian Population Census (table 2) is observed, despite the fact that the shares of the three other most numerous ethnic groups in the sample correspond quite accurately to those of the census. This can be partly explained by the outflow of the Russian population that continued after 2010, and partly by the large percentage of young age groups in our sample compared to official sources. Due to the fact that the birth rate of Russians in the KCR in the last decades of the 20th century was lower than that of non-Slavic peoples (see section 4), it is natural to expect that today in the young age groups $(15-19,20-24)$ the proportion of Russians will be less than in a wider age range. This is also observed in the results of VPN-2010: among women age 15-24, the share of Karachais and Russians was 44.1 and 26\%, respectively, that is, for Karachais the percentage at these ages was higher than among women 15-39 years old, and for Russians it was lower (the share of these ethnic groups among women aged 15-39 according to VPN-2010 is shown in Table 2). Consequently, the increased proportion of young ages compared to the census in our sample could have contributed to a decrease in the share of the Russian population in it.

Table 2. Distribution of sample respondents by nationality

\begin{tabular}{l|r|r|r}
\hline & Number & $\% *$ & $\begin{array}{c}\text { Share of women of this nationality among all } \\
\text { women 15-39 years old according to VPN-2010, \% }\end{array}$ \\
\hline Karachais & 416 & 56.4 & 42.8 \\
Circassians & 84 & 11.4 & 12.5 \\
Abazins & 65 & 8.8 & 7.8 \\
Russians & 112 & 15.2 & 29.3 \\
Nogais & 18 & 2.4 & 3.3 \\
Total & 737 & 100.0 & 95.7 \\
\hline
\end{tabular}

Note: * - of those indicating their nationality.

Thus, the distribution of respondents by age and ethnic strata did not fully correspond to the expectations formed by official statistics. However, the differences can be explained by demographic processes in the region.

Since the sample used quotas according to municipalities, the proportion of urban respondents at the time of the survey is predictably close to the current official statistics: $44.5 \%$ versus 42.72\% according to the Federal State Statistics Service as of January 1, 2018 (table 3). It is interesting to note that the proportion of women with an urban place of birth was almost 4.8 percentage points higher than the proportion of urban women at the time of the survey, which indicates a low intensity of rural-to-urban migration among women of the age groups studied. This assumption is consistent with the remark in Section 4 that the peak of this migration in the 
KCR was in the 1960s and 1970s, i.e., had occurred even before the birth of the respondents included in the survey. The presence of "reverse" urban-to-rural migration revealed by the survey requires a separate study. As can be seen from the data in Table 3, the largest excess of the share of women of urban birth compared to the share of urban residents at the time of the survey was recorded for the youngest age group (15-19 years old).

Table 3. Distribution of respondents by the share of urban residents, urban natives and those graduating from an urban school, \%

\begin{tabular}{c|c|c|c}
\hline Age groups & $\begin{array}{c}\text { Urban residents at the } \\
\text { time of the survey }\end{array}$ & Women with urban birth & $\begin{array}{c}\text { Graduating from school } \\
\text { in an urban settlement }\end{array}$ \\
\hline $15-19$ & 34.6 & 47.7 & 33.1 \\
$20-24$ & 51.2 & 50.3 & 44.5 \\
$25-29$ & 44.4 & 50.6 & 45.4 \\
$30-34$ & 39.6 & 44.4 & 42.1 \\
$35-39$ & 53.0 & 53.8 & 53.8 \\
Total & 44.5 & 49.3 & 43.7 \\
\hline
\end{tabular}

Table 4. Distribution of respondents by marital status at the time of the survey, by age group, \%

\begin{tabular}{c|c|c|c|c}
\hline Age groups & Never married & Married & Divorced & Widowed \\
\hline $15-19$ & 96.7 & 2.6 & 0.7 & 0.0 \\
$20-24$ & 78.0 & 18.9 & 1.2 & 1.8 \\
$25-29$ & 42.2 & 49.7 & 7.5 & 0.6 \\
$30-34$ & 26.4 & 52.1 & 19.4 & 2.1 \\
$35-39$ & 17.9 & 61.9 & 12.7 & 7.5 \\
\hline
\end{tabular}

Table 4 provides data on the marital status of respondents at the time of the survey by age group, and table 5 on "accumulated marriage" (the proportion of those who have been married at least once) by the time of the survey and at different age thresholds. In general, a rather late age model of nuptiality appears. It should be noted that the marriage "history" of a woman can be established from the survey only in a rather abbreviated form: the only question related to the age characteristics of marriage was related to the age at first marriage in years.

Table 5. Distribution of respondents by accumulated marriage, by age group, \%

\begin{tabular}{c|c|c|c}
\hline Age groups & $\begin{array}{c}\text { Share of those ever } \\
\text { married at the time of the } \\
\text { survey }\end{array}$ & $\begin{array}{c}\text { Share of those who } \\
\text { entered a first marriage at } \\
\text { age 22 or earlier }\end{array}$ & $\begin{array}{c}\text { Share of those who entered } \\
\text { a first marriage at age 25 or } \\
\text { earlier }\end{array}$ \\
\hline $15-19$ & 3.3 & - & - \\
$20-24$ & 22.0 & $24.2^{*}$ & - \\
$25-29$ & 57.8 & 36.9 & 54.4 \\
$30-34$ & 73.6 & 52.8 & 65.5 \\
$35-39$ & 82.1 & 53.7 & 72.4 \\
Total & 46.3 & $43.3^{*}$ & $63.5^{* *}$ \\
\hline
\end{tabular}

Note: * - share among those over 22 years old; ** - share among those over 25 years old.

It was not possible to obtain information about the age in years and months at marriage, due to the incomplete synchronization of religious and civil marriage characteristic of the KCR. A religious ceremony is always performed on wedding days, while registration with the registry office can take place several months after (among married respondents, 91\% reported that their marriage was registered with the registry office, but only $64.4 \%$ reported that registration took place "on the day of the wedding"). Under these conditions, respondents often found it difficult to 
determine their age at marriage to the precise number of months. Such accuracy was required from them during the pilot survey, according to the results of which it was decided to limit the question to the age in full years at the time of marriage.

Table 6. Proportion of women who studied at a higher educational institution, by age group, \%

\begin{tabular}{c|c}
\hline Age groups & $\begin{array}{c}\text { Studied at an institution of } \\
\text { higher education }\end{array}$ \\
\hline $15-19$ & 21.9 \\
$20-24$ & 67.9 \\
$25-29$ & 77.5 \\
$30-34$ & 74.1 \\
$35-39$ & 66.9 \\
Total & 61.9 \\
\hline
\end{tabular}

Let us now turn to the answers to questions regarding the education of a woman, her position in the labor market and the material situation of the household to which she belongs (table 6). The level of education recorded in the sample is significantly higher than that reflected in the 2010 census (there the proportion of women with higher or incomplete higher education in the age group 20-24 years old was 37\%, 25-29 years old - 33\%, 30-34 years - 25\%, 35-39 years $18 \%$ ). In connection with this discrepancy, two points can be made. On the one hand, the increase in the share of those with a higher level of education observed in the VPN-2010 from older to younger generations was likely to be continued in the years following the census. This is suggested by our "qualitative" field observations, according to which in the last 10-15 years in the KCR the idea that ensuring a young woman's studies at the university (at least by correspondence) is one of the parents' responsibilities has become increasingly widespread. In this sense, the higher level of education seen in the 2018 survey compared with VPN-2010 does not seem unexpected. On the other hand, such a high level of education as recorded in the survey still does not seem realistic. One of the probable reasons for its occurrence is the mass refusals of interviews noted by our interviewers among women for whom we can assume a low level of education (housewives, those living in remote villages, etc.). In addition, a large proportion of respondents living in Cherkessk (determined by quotas for municipalities - see above) could also increase the overall percentage of respondents with a high level of education, since in Cherkessk there are more higher educational institutions of the region, as well as institutions and enterprises hiring people with higher education. Thus, we have to admit a certain bias in our sample from the point of view of the educational level, which is partially explained by certain features of the survey (we cannot accurately assess the extent of this bias without alternative current estimates of the educational level of women by generations; in the statistical analysis presented in Section 6, the bias problem was partially solved by the obligatory introduction of the education parameter in the model as a control).

For an "external" verification of the reliability of the survey in terms of assessing demographic indicators, we made a comparison of the fertility data from the survey with the data of the largest population surveys conducted in the KCR over the past decade: VPN-2010 and the 2015 Rosstat microcensus (MP-2015). To do this, based on data on the year and month of birth of each woman interviewed and of each of her children, the number of children born by the time of MP-2015 and by the time of VPN-2010 was determined, and from these data the average 
accumulated fertility for five-year age groups at the time of MP-2015 and VPN-2010 was calculated. Then, these "retrospective" survey indicators were compared with the indicators calculated for the same five-year groups in the KCR directly according to the data of MP-2015 and VPN-2010 (since our survey did not include women over 39 at the time of the survey, it was not possible to compare ages 30-34 and 35-39 at the time of VPN-2010 and for ages 35-39 at the time of MP-2015). The results are shown in table 7, where the values calculated according to the data of MP-2015 and according to the survey data are given with confidence intervals; coverage of the VPN-2010 population did not require the use of confidence intervals. As can be seen from table 7, there is a fairly exact match of the average number of children for VPN-2010, whereas for the time of MP-2015, the survey recorded lower birth rates than MP-2015 itself. Despite all criticism of the reliability of the VPN-2010 results for the North Caucasus, the closeness of the data from this largest population survey to our survey data seems to be a definite argument in favor of the latter's adequacy.

Table 7. Comparison of the average number of children per woman by age groups in the KCR according to VPN-2010, MP-2015 and according to the survey at the time of VPN2010 and MP-2015

\begin{tabular}{c|c|c|c|c}
\hline $\begin{array}{c}\text { Age } \\
\text { groups }\end{array}$ & $\begin{array}{c}\text { Average number of } \\
\text { children according to the } \\
\text { survey at the time of } \\
\text { VPN-2010, by age during } \\
\text { VPN-2010* }\end{array}$ & $\begin{array}{c}\text { Average } \\
\text { number of } \\
\text { children } \\
\text { according to } \\
\text { VPN-2010 }\end{array}$ & $\begin{array}{c}\text { Average number of } \\
\text { children according to the } \\
\text { survey at the time of MP- } \\
2015, \text { by age at the time } \\
\text { of MP-2015* }\end{array}$ & $\begin{array}{c}\text { Average number of } \\
\text { children according to } \\
\text { MP-2015* }\end{array}$ \\
\hline $15-19$ & $0.047(0.000 ; 0.097)$ & 0.037 & $0.023(0.000 ; 0.049)$ & $0.047(0.018 ; 0.075)$ \\
$20-24$ & $0.372(0.274 ; 0.469)$ & 0.373 & $0.313(0.208 ; 0.418)$ & $0.476(0.393 ; 0.559)$ \\
$25-29$ & $0.903(0.736 ; 1.070)$ & 0.919 & $0.927(0.762 ; 1.092)$ & $1.190(1.092 ; 1.289)$ \\
$30-34$ & - & 1.587 & $1.358(1.161 ; 1.556)$ & $1.609(1.489 ; 1.729)$ \\
\hline
\end{tabular}

Note: * - average and boundaries of confidence intervals at a 95\% significance level; MP - microcensus of Rosstat 2015

Table 8. Shares of respondents who gave specific answers to questions about education, their situation on the labor market and their contribution to family income, by age group, $\%$

\begin{tabular}{c|c|c|c|c|c}
\hline Age groups & $\begin{array}{c}\text { Studied after } \\
\text { graduating from } \\
\text { high school }\end{array}$ & $\begin{array}{c}\text { Working at the } \\
\text { time of the } \\
\text { survey }\end{array}$ & $\begin{array}{c}\text { Studied after } \\
\text { getting married* }\end{array}$ & $\begin{array}{c}\text { Worked after } \\
\text { getting married* }\end{array}$ & $\begin{array}{c}\text { Contributes to } \\
\text { family income* }\end{array}$ \\
\hline $15-19$ & 55.5 & 23.1 & 60.0 & 40.0 & - \\
$20-24$ & 91.8 & 64.0 & 37.8 & 57.9 & 14.3 \\
$25-29$ & 95.6 & 78.0 & 45.2 & 61.8 & 30.9 \\
$30-34$ & 93.0 & 76.6 & 48.0 & 65.4 & 35.8 \\
$35-39$ & 88.0 & 81.5 & 39.3 & 67.6 & 42.7 \\
Total & 85.0 & 64.5 & 43.6 & 64.0 & 33.3 \\
\hline
\end{tabular}

Note: * - share among those who are married.

Let us now turn to the distribution among the respondents of the characteristics that in Section 2 we classified as indicators of the traditional family structure. In table 6 we have already seen the age distribution of women enrolled in higher education. Table 8 shows the distribution of other characteristics related to the education of a woman and her work outside the household. Unidirectional intergenerational dynamics have two characteristics that are specific only for married women: the proportion of those who worked after marriage and the proportion of those 
who at the time of the survey contributed to family income. An increase in these indicators to younger ages may indicate a strengthening of gender asymmetries for younger generations, but it can also be explained by the deterioration of labor market conditions, as a result of which young women have difficulties in finding work.

Table 9 shows the age distribution of characteristics that we consider as evidence of the existence of generational hierarchies in a woman's family. Table 9 shows that marriage at the initiative of older relatives is not the predominant practice, but it is still quite common, at least at the stage of meeting future spouses, and unidirectional intergenerational dynamics are not observed.

Table 9. Proportion of respondents giving specific answers to questions regarding generational asymmetries, by age groups, \%

\begin{tabular}{c|c|c|c|c|c}
\hline Age groups & $\begin{array}{c}\text { Met future } \\
\text { spouse } \\
\text { without } \\
\text { participation } \\
\text { of relatives* }\end{array}$ & $\begin{array}{c}\text { Independently made } \\
\text { decision to marry* }\end{array}$ & $\begin{array}{c}\text { Lives with } \\
\text { husband's } \\
\text { elder relatives }\end{array}$ & $\begin{array}{c}\text { Parents and/or } \\
\text { husband's } \\
\text { parents } \\
\text { participate in } \\
\text { raising } \\
\text { children** }\end{array}$ & $\begin{array}{c}\text { Considers it } \\
\text { important to teach } \\
\text { their children } \\
\text { about the } \\
\text { traditions of their } \\
\text { people }\end{array}$ \\
\hline $15-19$ & 60.0 & & & - & 34.0 \\
$20-24$ & 60.5 & 60.0 & 84.0 & 69.6 & 39.0 \\
$25-29$ & 77.4 & 95.7 & 61.0 & 76.1 & 36.2 \\
$30-34$ & 68.3 & 82.5 & 50.3 & 64.1 & 37.6 \\
$35-39$ & 71.0 & 85.0 & 38.9 & 55.3 & 33.8 \\
Total & 70.6 & 87.2 & 63.2 & 64.4 & 38.1 \\
\hline
\end{tabular}

Note: * - share among married women; **-share among those with at least one child.

Table 9 (continued)

\begin{tabular}{c|c|c|c}
\hline Age groups & $\begin{array}{c}\text { Needs approval of older } \\
\text { relatives to move to another } \\
\text { region }\end{array}$ & $\begin{array}{c}\text { Needs approval of older } \\
\text { relatives to get married }\end{array}$ & $\begin{array}{c}\text { Needs approval of older } \\
\text { relatives to change place of } \\
\text { residence within same } \\
\text { locality }\end{array}$ \\
\hline $15-19$ & 90.5 & 69.4 & 88.5 \\
$20-24$ & 83.0 & 60.1 & 79.6 \\
$25-29$ & 75.2 & 54.8 & 72.6 \\
$30-34$ & 69.3 & 56.3 & 65.9 \\
$35-39$ & 72.9 & 56.3 & 64.1 \\
Total & 78.5 & 59.5 & 74.6 \\
\hline
\end{tabular}

More than half of the respondents reported the participation of older relatives in raising their children, as well as cohabitation with older relatives of a husband, and the prevalence of both of these phenomena is growing from older generations to younger ones. This may be due to a certain "retraditionalization" of the family structure, but it can also be explained by the fact that young families are less "economically stable" and therefore more dependent on older relatives, and also experience significant difficulties in purchasing or renting separate housing. As for the dependence on older relatives when making certain life decisions, it, as can be seen from table 9, turned out to be very strong in general: over $50 \%$ of respondents expressed the need for older relatives to approve a move to another region or locality and to approve their decision to get married or divorced. Moreover, we can see a percentage growth of those in younger age groups requiring such approval relative to older age groups (which again can be seen as evidence of "retraditionalization", or as evidence of a late "separation" of the young generation from parents 
and older relatives, a high level of "care" on the part of the elders due to the economic lack of independence of young people, or the difficulties that young people face in finding work).

Table 10. Interethnic differences of respondents related to family "traditionalism"

\begin{tabular}{|c|c|}
\hline Characteristic & $\begin{array}{l}\text { Differences between Karachais and other ethnic groups } \\
\text { in the proportion of women who have a positive value } \\
\text { for this attribute (significance at a } 95 \% \text { level) }\end{array}$ \\
\hline Has steady job at time of the survey & Insignificant \\
\hline Wife contributes to family income & Insignificant \\
\hline $\begin{array}{l}\text { Herself decided to marry her current spouse (and did } \\
\text { not marry by the decision of relatives). }\end{array}$ & Among Karachais significantly lower \\
\hline Met future spouse on her own & Among Karachais significantly lower \\
\hline $\begin{array}{l}\text { Among the parents of the woman and her husband } \\
\text { there are fellow villagers }\end{array}$ & Insignificant \\
\hline Received professional education after marriage & Insignificant \\
\hline $\begin{array}{l}\text { Considers it important to teach the children about the } \\
\text { traditions of her people }\end{array}$ & Among Karachais significantly higher \\
\hline $\begin{array}{l}\text { Needs approval of older relatives to get married or } \\
\text { divorced }\end{array}$ & Among Karachais significantly higher \\
\hline $\begin{array}{l}\text { Needs approval of older relatives to move to another } \\
\text { region }\end{array}$ & Among Karachais significantly higher \\
\hline $\begin{array}{l}\text { Needs approval of older relatives to change place of } \\
\text { residence within the same locality }\end{array}$ & Among Karachais significantly higher \\
\hline $\begin{array}{l}\text { Lives together with older relatives (her own or her } \\
\text { husband's) }\end{array}$ & Among Karachais significantly higher \\
\hline
\end{tabular}

The distribution of characteristics that we consider to be indicators of the "traditional" family structure was studied not only in terms of age groups, but also in ethnic terms. It was found that one of the ethnic groups of the region (Karachais) according to the survey significantly differs from other peoples in a more traditional family way. Table 10 summarizes the comparison of respondents of Karachai nationality and respondents of all other nationalities according to the parameters of family "traditionalism". For respondents from Karachai and other nationalities, the average values of the dichotomous parameters given in the table were calculated separately, each of which received a value of 1 if the respondent had the corresponding attribute, and 0 if she did not. Comparison of the average values of most of these parameters revealed differences at a 95\% significance level, and in all such cases the Karachais differ in the direction of greater "traditionality". A similar distribution of significant and insignificant differences was provided by the use of the non-parametric Mann-Whitney test (with the exception of the parameter of living with older relatives, according to which this test rated interethnic differences as insignificant; the results of the Mann-Whitney test are not shown here $)^{5}$.

\footnotetext{
${ }^{4}$ Obviously, with regard to married women, such a conclusion would have been more correct to draw, taking into account the nationality of not only the woman herself, but also her husband. However, the share of interethnic marriages among the respondents of Karachai nationality turned out to be only $11 \%$ (with $24 \%$ for the entire sample). Therefore, it would not be incorrect to consider that the differences between the answers of women of Karachai and those of other nationalities reflect the differences between the Karachai and non-Karachai families. ${ }^{5}$ It should be noted that the significant differences between the Karachai respondents and those of other nationalities towards greater family "traditionalism" cannot be explained by the contrasts between these groups in urban / rural living, since the shares of rural residents among Karachais and respondents of other nationalities were very close: 54.4 and $56.9 \%$, respectively.
} 


\section{ANALYSIS}

Our analysis focuses on the age of a woman's first marriage. Such a choice was dictated by the following considerations. First, as noted in section 3, a young age at marriage is considered in numerous studies to be linked to the traits of a traditional family structure, and it was of interest to test this link for the society here studied. Secondly, the age of marriage in the case of the KCR determines fertility to a greater extent than, for example, in today's Russia as a whole or in Western Europe. The reason is the region's extremely low level of extramarital fertility. According to the survey, only two respondents who have never been married had children. Under such conditions, the age at which a woman marries is a determining factor for the age at birth of her first child, and this age, in turn, is expected to affect fertility (Bongaarts 1999). Thus, it can be assumed that the age at first marriage in the case of KCR will be a "root" indicator that will significantly affect other characteristics of marital and reproductive behavior.

It is necessary to stipulate one important limitation associated with the choice of the age at first marriage as a dependent variable in the analysis. As already mentioned in Section 5, according to the results of the survey we only had information about a woman's age in full years when entering into her first marriage. This meant a coarsening of the statistical analysis, whose increments could be only annual, not monthly ${ }^{6}$.

In analyzing the survey results, we tested two hypotheses.

- Hypothesis 1. Characteristics of traditionalism are significant for marriage age.

- Hypothesis 2. The Karachais differ from other ethnic groups in age characteristics of marriage.

Hypothesis 1 follows from the results of studies of different countries and regions that are briefly summarized in Section 3. Hypothesis 2 was put forward taking into account the results of the same studies, as well as the higher "traditionality" of Karachai families indicated by the survey (see above). Note that testing the second hypothesis with the most obvious "descriptive" method did not confirm it: there was no difference at the $95 \%$ significance level between the average marriage age of the Karachai respondents and those of other nationalities. However, this could be due to some other signs that were significant for the age at first marriage, for which respondents of different nationalities in our sample may differ; therefore, for a more reliable result, it was necessary to test Hypothesis 2 by including the ethnicity parameter in the model along with control parameters.

\footnotetext{
${ }^{6}$ One of the consequences of the fact that the analysis could include data on the age at which women entered into their first marriage only up to full years, was the difficulty of a statistical analysis of the factors affecting the woman's age at the birth of her first child. Although the data on this age parameter from the survey were available to the nearest month, the exact number of months that elapsed between marriage and the birth of the firstborn could not be determined. This posed a choice: either to analyze the factors affecting the age of birth of the first child, without taking into account the age of marriage (however, ignoring the length of marriage for such an analysis is incorrect), or to coarsen data on the age at birth of a child up to full years (but, given that the average difference between the number of full years at the birth of the first child and at marriage is less than 2.5 years, with such an analysis it would be difficult to obtain statistically significant results due to the small number of person-years that would be "left" after right-censoring). In such a situation, it seems more appropriate to investigate the age characteristics of fertility, using as the dependent parameter not the age of motherhood, but the number of children with different age ranges. Such an analysis will be undertaken in the course of further processing of the survey results.
} 
Two types of models were built: proportional risk models (with Cox regression ${ }^{7}$ ), in which the modeled event was the woman's first marriage, and logistic models for the probability of marriage at different ages up to 25 years.

In the models of proportional risks, the dependent variable was the risk of marriage, defined for the age of respondents in full years starting from age 15 years and 0 months (i.e., for the 16th, 17 th, etc. years of life). For women who were not married, the analysis included all full years until the time of the survey; for married women, the years lived after this event were not included in the analysis (so-called right censoring was carried out). Since only fully lived years were included in the analysis, women who got married at the same age in full years as they were at the time of the survey were excluded from the analysis (for previous experience in applying the proportional risk model for analyzing the demographic behavior of the population of the North Caucasus, see (Mitrofanova 2019)).

All models included the following parameters characterizing the generational and social characteristics of women:

- the woman's year of birth (at five-year intervals: 1979-1983, 1984-1988, 19891993, 1994-1998, 1999-2003);

- $\quad$ place of birth (city/village);

- having higher or incomplete higher education;

- having a job at the time of the survey.

The first two were control parameters. The parameters related to education and work were considered above as being among the indicators of gender asymmetries in a woman's family. However, while other indicators of gender asymmetries, as well as indicators of generational asymmetries, were included selectively in different combinations in the models, the parameters of work and education were included (simultaneously or one at a time) in all models. This decision is due to the fact that a woman's education and employment are known as factors that universally affect fertility, and a correlation is expected for them with other parameters acting as independent in the models (for example, a lower level of education is expected for rural women). Thus, the non-inclusion of the parameters of education and labor activity in the model could lead to biases.

It should be noted that due to the peculiarities of the proportional risk models, all independent parameters included in them must either have the same value for all time intervals lived by a woman (in our case, person-years) included in the analysis, or be specified separately for each such interval. At the same time, employment and education are acquired during the course of one's life and, strictly speaking, it is incorrect to consider the meanings of these parameters as constant over the entire interval from 15 years to the time of the survey or the first marriage. However, taking into account that more than $90 \%$ of respondents who continued their education after leaving school began it before the age of 19, it can be said that the presence of higher education is a parameter that uniformly characterizes almost the entire reproductive period of a

\footnotetext{
${ }^{7}$ For the application of such models to the analysis of demographic events, see (Burdyak 2007).
} 
woman, except for the initial part. It is also important to take into account that educational plans for the near future are very likely to affect the matrimonial behavior of women at the earliest reproductive age, thus reducing the likelihood of marriage at this age. As for employment outside the household, it was not possible to establish its presence or absence at different ages in full years during the survey: a pilot survey showed that it was difficult for respondents to restore their "work biography" in one-year increments. Thus, it seemed the only possibility was to characterize a woman's employment as being either present or absent at the time of the survey.

Table 11. Models of proportional risks for women in the first marriage (according to the survey)

\begin{tabular}{|c|c|c|c|c|c|c|}
\hline $\begin{array}{l}\text { Parameters } \\
\text { Year of birth }\end{array}$ & (1) & (2) & (3) & (4) & (5) & $(6$ \\
\hline $1979-1983$ & 1 & 1 & 1 & 1 & 1 & 1 \\
\hline 1984-1988 & $0.796 *$ & 0.814 & 0.849 & 0.863 & 0.814 & 0.823 \\
\hline $1989-1993$ & $0.545^{* * * *}$ & $0.551 * * *$ & $0.565 * * *$ & $0.568^{* * * *}$ & $0.560 * * *$ & $0.558^{* * *}$ \\
\hline 1994-1998 & $0.262 * * *$ & $0.248 * * *$ & $0.263 * * *$ & $0.245^{* * * *}$ & $0.250 * * *$ & $0.231^{* * *}$ \\
\hline $1999-2003$ & $0.087 *$ & $0.094 * *$ & $0.074 * *$ & $0.079 * *$ & $0.061 * * *$ & $0.064 * * *$ \\
\hline Urban place of birth & 0.850 & 0.867 & 0.864 & 0.878 & 0.900 & 0.916 \\
\hline $\begin{array}{l}\text { Has higher or } \\
\text { incomplete higher } \\
\text { education }\end{array}$ & & & $0.621 * * *$ & $0.634 * * *$ & $0.666 * * *$ & $0.685^{* * * *}$ \\
\hline $\begin{array}{l}\text { Working at the time } \\
\text { of the survey }\end{array}$ & & & & & $0.639 * * *$ & $0.633^{* * *}$ \\
\hline Karachai & & $0.731^{* * *}$ & & $0.748 * * *$ & & $0.729 * * *$ \\
\hline $\mathrm{N}$ & 699 & 699 & 689 & 675 & 672 & 659 \\
\hline -2Log credibility & 3743.962 & 3668.598 & 3703.164 & 3628.954 & 3571.276 & 3497.664 \\
\hline Chi-square models & $55.971 * * *$ & $64.358 * * *$ & $68.575 * * *$ & $75.957 * * *$ & $78.001 * * *$ & $84.540 * * *$ \\
\hline
\end{tabular}

Note: $* p<0.1, * * p<0.05, * * * p<0.001$.

When testing Hypothesis 1 in the proportional risk model, along with the parameters listed above, the following parameters characterizing the "traditionalism" of the family structure were included in different combinations (for the rationale for using these parameters, see Section 2):

- acknowledging the importance of teaching children about the traditions of their people;

- the need to obtain the approval of older relatives for marriage;

- the need to obtain the approval of older relatives to move to another region;

- the need to obtain the approval of older relatives when changing their place of residence within the same location;

- living together with older relatives (their own or their husband's) ${ }^{8}$.

All the parameters of this list for the risks of first marriage were insignificant, thereby refuting Hypothesis 1 (the corresponding models are not shown here for reasons of space and can be sent by the author upon request).

\footnotetext{
${ }^{8}$ Of the indicators of the traditional family structure discussed in Section 2, those that are only identifiable for married women were not included in the model.
} 
Hypothesis 2, on the contrary, has been confirmed in proportional risk models. The corresponding models are shown in Table 11. It should be noted that there are differences in the sample size between the specific models given below, due to the fact that some respondents refused to answer most of the questions asked during the survey. For each model, the sample size was equal to the number of respondents for whom, based on their answers, it is possible to determine all the parameters included in this model. The sample size is indicated separately for each model. Differences in these sizes are not an obstacle for comparing the significance of the same parameter in different models.

From the models in Table 11, it is easy to see, firstly, that the risks of a first marriage significantly decrease from older cohorts to younger ones. They are also significantly lower for women studying in higher educational institutions and for women who had jobs at the time of the survey. The parameter of the place of birth (rural or urban) turned out to be insignificant (as did the parameters introduced in the model instead of it, indicating the completion of school in an urban or rural settlement and urban/rural residence; the corresponding models are not shown for reasons of space). Finally, the risks of a first marriage for women of Karachai nationality were significantly lower than for respondents of other nationalities.

Table 12. Logistic model for marriage at 22 years of age or earlier (according to the survey; only for respondents who were 22 years old at the time of the survey)

\begin{tabular}{lc|c|r}
\hline & Standard error & Wald & $\operatorname{Exp(B)}$ \\
\hline $1979-83$ & & 9.056 & 0.717 \\
$1984-88$ & 0.278 & 1.430 & $0.417^{* * *}$ \\
$1989-93$ & 0.301 & 8.484 & $0.553^{*}$ \\
$1994-98$ & 0.370 & 2.572 & 0.844 \\
Living in the city at time of survey & 0.266 & 0.409 & $0.409^{* * *}$ \\
$\begin{array}{l}\text { Has hes. 0 - no) } \\
\text { education }(1-\text { yes. } 0 \text { - no) }\end{array}$ & 0.232 & 14.825 & $0.695^{*}$ \\
Karachai $(1-$ yes. $0-$ no) & 0.223 & 2.657 & 1.099 \\
Constant & 0.285 & .110 & \\
\hline
\end{tabular}

Note: $N=497, R^{2}$ Nigelkirke $=0.112 ; * p<0.1, * * p<0.05, * * *<<0.001$.

The significance of the ethnicity parameter found in the proportional risk models was also confirmed in logistic regressions, in which the modelled event was entering first marriage by the age of 22, 23 and 24 (for respondents who reached the corresponding age at the time of the survey). These models confirmed the "aging" of the marriage model in the region as a whole (significantly lower chances of marriage at these ages among younger cohorts), and revealed a negative significance of studying at a higher educational institution for entering a first marriage by these ages. As for the ethnicity parameter, women of Karachai nationality had a lower chance of getting married at these ages than women of other nationalities, at a 90\% significance level. Table 12 shows the logistic model for the fact of marriage by the age of 22 (in the models built for age 23 and 24, the significance levels of the parameters and the "signs" of the coefficients were the same).

\section{DISCUSSION OF ANALYSIS RESULTS}

A significant reduction in the risks of marriage from older to younger generations generally fits into the all-Russian tendency towards an increase in the age at first marriage in the post-Soviet 
decades (Zakharov 2018: 131-149). However, given that a number of generations covered by the survey were far from completing their reproductive period at the time of the survey, it is impossible to determine to what extent this result indicates an increase in the age of the first marriage, and to what extent an increase in the share of those never marrying.

The negative significance of a woman's educational level and employment for marriage is consistent with well-known global trends. In the light of the starting assumptions of our analysis, this significance could also be considered as a confirmation of the influence of characteristics of family traditionalism on marriage. However, such an interpretation raises questions because for other parameters of traditionality no significant connection with nuptiality was found. At the same time, a woman's level of education and her job (unlike, for example, her right to make certain life decisions independently) may be a consequence of not only the family's way of life, but also of factors "external" to the family, such as the labor market, the availability of educational services, etc. As for the lack of significance of the rural/urban residence parameter, this rather unexpected result requires further reflection.

We turn now to the significance of the ethnicity parameter. Confirmation of Hypothesis 2 in the course of our analysis, along with interethnic differences established by descriptive methods in Section 5 (Table 10), lead us to the following conclusion: the Karachai ethnos, to a greater extent than other peoples, retains signs of a traditional family structure, yet at the same time it is characterized by a later age of first marriage ${ }^{9}$. From the point of view of expectations based on studies of other countries and regions, which are summarized in Section 3, such a result is paradoxical. However, the tendency toward later marriage among women of Karachai nationality indicated by the results of our modeling also is indirectly confirmed by the data of the 2010 AllRussian Population Census.

As was already mentioned, this census did not collect data on the age of marriage, but did collect data on the age of a woman at the birth of her first child. Figures P1-P7 of the Appendix compare the cumulative probability of "surviving" childless to different ages for women of the Karachai and the two other largest non-Slavic ethnic groups of the KCR (Circassians and Abazins) for birth cohorts according to VPN-2010. It is easy to see that in all cohorts, starting from the cohort of 1950-54, Karachai women were characterized by a later "start" of motherhood (for cohorts who lived to be 40 years old at the time of VPN 2010, we can also note a slight excess among the Karachai of women who remained childless) That is, we can talk about the interethnic difference in the age-specific fertility model observed from generation to generation for at least several decades. The data of VPN-2010, of course, do not allow us to answer the question of what the regularly later "start" of motherhood among Karachais is connected with: with an older age of women getting married or with the postponement of first births in marriage. Nevertheless, the tendency revealed by the survey toward later marriage among women of Karachai nationality, in the context of an extremely low level of illegitimate birth rates, allows us to predict an older average age at the birth of their first child, and this prediction is confirmed by census data. It is also important to note that the differences identified by VPN-2010 were already found for women

\footnotetext{
${ }^{9}$ Since the reproductive period in the cohorts included in the study is not completed, it is, strictly speaking, impossible to determine whether this result is due to women of Karachai nationality postponing their first marriage or to the greater proportion of childlessness among them.
} 
born in the 1950s, i.e., those born and undergoing primary socialization even before the mass ruralto-urban migration of non-Slavic peoples of the KCR (see section 4). So, the VPN-2010 data reflect a difference in the age characteristics of demographic behavior dating back to the period when the main non-Slavic peoples of the KCR lived mainly in rural settlements. Thus, the age differences in question are most likely to indicate a difference in age-related behaviors in traditional models of demographic behavior of ethnic groups. And if so, then the later nuptiality among Karachais can be explained precisely by the greater preservation of their traditional family structure, which we discovered from the survey.

Consequently, contrary to the expectations formed by existing marriage studies outside of Western Europe and North America, signs of a traditional family pattern do not necessarily correlate with a woman's earlier age at marriage. Using the example of the KCR, we have seen precisely an opposite picture, i.e. an ethnic group characterized by a more traditional family structure compared to other ethnic groups in the region and showing a later age pattern of marriage. Such a result does not contradict the concept of the traditional family structure as a family organization in which each next generation is required to reproduce certain "patterns" of ancestral behavior. However, this result does compel us to admit that these patterns may vary, and that they may prescribe a relatively late onset of demographic events. If in a given society the norms of the traditional family structure play a significant role, it is appropriate to assume only the existence of age-related patterns of matrimonial behavior, but not specific characteristics of the age of marriage. And if in different ethnic groups the relationship between the features of the traditional family structure and the age of the first marriage may be multidirectional, it should not be surprising that in the sample combining all the ethnic groups of the region we have studied, these features do not show a significant unidirectional relationship with the age at which a woman got married.

We add that the combination of features of a traditional family structure with a fairly late age of marriage for women in the North Caucasus is, apparently, observed not only in KarachayCherkessia. A survey of women 16-44 years old in the Republic of Ingushetia, conducted by us in 2019, showed that in this region the average age of a woman at her first marriage for those who had reached the age of 40 at the time of the survey was over 24 years old (the survey was conducted by telephone interview and included 800 respondents). Ingushetia differs from the KCR by a significantly higher "preservation" of many features of family traditionalism (in particular, as the survey showed, the percentage of marriages on the initiative of the older relatives of the bride and groom is much higher than in the KCR, the woman is more dependent on older members family when making various important life decisions, etc.). At the same time, a preliminary analysis of the survey results showed that among sociocultural parameters, parameters characterizing a woman's personal religiosity are significantly related to a younger age of marriage, but not parameters that are indicators of a traditional family structure.

The conclusion of our analysis has some implications for studies of demographic processes in developing countries. The large-scale increase in many of these countries of the average age of the "start" of motherhood, which began in the last third of the last century (Bongaarts 1999), is considered to be one of the components of demographic modernization, a departure from the traditional attitudes of marital and reproductive behavior. However, in the light of the results obtained, it must be borne in mind that the absolute value of the average age of a woman at some demographic event, even if it is high compared to other developing countries, cannot be 
automatically considered as evidence of family modernization: this value can also comply with local age-specific standards.

However, the question remains as to what determines the "direction" of the relationship between family traditionalism and the age at marriage. Was this "tradition of late marriage" among the Karachai people determined by some social processes that unfolded during the Stalin deportation of 1943-1957, or does it go back to more ancient customs? The answers to such questions, of course, require a separate study.

\section{Conclusions}

The article examined the relationship between the characteristics of the family structure and the age of a woman upon her first marriage in one of the regions of the North Caucasus - KarachayCherkessia. The study was based on the results of a survey of women of reproductive age that we conducted in the KCR in 2018. The survey showed that in this region some features of a traditional family structure regarding gender and generational asymmetries are quite widespread. Moreover, the influence of family "traditionalism" on the age characteristics of marriage was not at all unexpected based on studies conducted in other countries and regions. The most unexpected result, however, is that an ethnic group characterized by a higher degree of preservation of the norms of a traditional family way of life exhibits a statistically significant tendency to later marriage of women. It follows that the relationship between family norms and age characteristics of demographic events may be more diverse than is assumed on the basis of previous studies of this issue. The data of the North Caucasus, which is distinguished by a noticeable variability of the models of marital and reproductive behavior, as well as of the characteristics of the family structure, can provide many more opportunities for studying the relationships between them. As regards the KCR, the next step, it would seem, should be the study of the significance of family norms for age parameters of fertility.

\section{ACKNOWLEDGEMENT}

The survey in Ingushetia, the results of which are discussed in Section 7, was carried out as part of the 2019 RANEPA research and development program "Analysis of the possibilities of using online research on the demographic characteristics of traditional communities". The author gives thanks to S.V. Zakharov, V.A. Kozlov, E.S. Mitrofanova and A.I. Raksha for regular discussions on the results of research on marriage and fertility in the North Caucasus.

\section{REFERENCES}

Agarwala R., Lynch S.M. (2006). Refining the Measurement of Women's Autonomy: An International Application of a Multi-dimensional Construct. Social Forces, 84(4), 2069-2090. doi: 10.1353/sof.2006.0079

Ahearn L. (2001). Invitations to love: literacy, love letters, and social change in Nepal. Ann Arbor: University of Michigan Press. 
Belozerov S.V. (2005) Etnicheskaja karta Severnogo Kavkaza [The ethnic map of the North Caucasus]. Moscow: O.G.I. 302 p. (In Russ.)

Bongaarts J. (1999). The fertility impact of changes in timing of childbearing in developing world. Population Studies, 53(3). 277-289. doi: 10.1080/00324720308088

Burdjak A.Ja. (2007). Primenenie metoda "analiza nastuplenija sobytija" s pomoshchju paketa SPSS [Using the event history analysis method in SPSS]. Spero, 6, 189-202 (In Russ.).

Collier J. (1997). From duty to desire: remaking families in a Spanish village. Princeton: University Press.

Dommaraju P., Agadjanian V. (2008). Nuptuality in Soviet and post-Soviet Central Asia. Asian Population Studies, 4(2), 195-213. doi: 10.1080/17441730802247463

Dyson T., Moore M. (1983). On Kinship Structure, Female Autonomy, and Demographic Behaviorin India. Population and Development Review, 9(1), 35-60. doi: 10.2307/1972894

Gruber S., Szołtysek M. (2012). Quantifying Patriarchy: An Explorative Comparison of Two Joint Family Societies. MPIDR Working Paper WP 2012-017, April 2012. Retrieved from https://www.demogr.mpg.de/en/projects_publications/publications_1904/mpidr_working_pa pers/quantifying_patriarchy_an_explorative_comparison_of_two_joint_family_societies_460 4.htm

Hajnal J. (1965). European marriage pattern in historical perspective. In D.V.Glass, D.E.C.Eversley (Eds.) Population in History. London: Arnold.

Hart K. (2007). Love by Arrangement: The Ambiguity of 'Spousal Choice' in a Turkish Village. The Journal of the Royal Anthropological Institute, 13(2), 345-362. doi.org/10.1111/j.14679655.2007.00438.x

Karpov Ju.Ju. (2001). Zhenskoe prostranstvo v kul'ture narodov Kavkaza [The female sphere in the culture of peoples of the Caucasus]. Saint-Petersburg: Peterburgskoe vostokovedenie. 419 p. (In Russ.)

Kaser K. (2002). Power and inheritance: male domination, property and family in Eastern Europe, 1500-1900. History of the Family. 7, 375-395.

doi: 10.1016/S1081-602X(02)00109-4

Kazenin K.I., Kozlov V.A. (2017a). Osobennosti brachno-reproduktivnogo povedenija naselenija v Respublike Dagestan: ikh prichiny i social'no-ekonomicheskie posledstvija [Special characteristics of nuptiality and fertility in Daghestan: their reasons and socialeconomic consequences]. Vestnik Instituta ekonomiki RAN [The Bulletin of the Institute for Economics, Russian Academy of Science], 2, 65-81 (In Russ.).

Kazenin K.I., Kozlov V.A. (2017b). Vozrast materinstva v Dagestane: znachimost' etnicheskogo faktora v uslovijakh modernizacii [Mother's age in Daghestan: the role of ethnicity in the process of globalization]. Narodonaselenie [Population], 1, 46-58 (In Russ.).

Lerch M. (2013). Patriarchy and fertility in Albania. Demographic Research, 29, 133-166. doi: 10.4054/DemRes.2013.29.6

Malhotra A., Vannemann R., Kisher S. (1995). Fertility, Dimensions of Patriarchy, and Development in India. Population and Development Review, 21(2), 281-305. doi: $10.2307 / 2137495$

Mason K. O. (1987). The Impact of Women's Social Position on Fertility in Developing Countries. Sociological Forum, 2(4), 718-745. doi: 10.1007/BF01124382 
Mitrofanova E.S. (2019). Entering adult life: North Caucasus in comparison to other regions of Russia. Journal of Social Policy Studies, 17(1), 133-141 (in Russ.). doi: 10.17323/727-06342019-17-1-133-141

Molodikova I., Watt A. (2014). Growing up in the North Caucasus: society, family, religion and education. London: Routledge. 202 p.

Morgan S.P., Stash S., Smith K., Mason K.O. (2002). Muslim and Non-Muslim Differences in Female Autonomy and Fertility: Evidence from Asian Countries. Population and Development Review, 28(3), 515-538. doi.org/10.1111/j.1728-4457.2002.00515.x

Pavlova O.S. (2012). Ingushskij etnos na sovremennom etape. Cherty social'nopsikhologicheskogo portreta [Ingush people today. Social-psychological characteristics]. Moscow: Forum. 384 p. (In Russ.)

Pavlova O.S. (2013). Chechenskij etnos segodnja: cherty social'no-psikhologicheskogo portreta [Chechen people today: social-psychological characteristics]. Moscow: Sam Poligrafist. 588 p. (In Russ.)

Sabanchieva L.Kh. (2016). Gender v social'no-politicheskikh processakh v Kabardino-Balkarii (20-e gg. XX v. - nachalo XXI veka) [Gender in sociopolitical processes in KabardinoBalkaria (from 1920es - to eraly 21 century)]. Nal'chik: KBIGI. 158 p. (In Russ.)

Starodubrovskaya I.V. The crisis of the traditional North Caucasian family in the post-Soviet period and its consequences. Journal of Social Policy Studies, 17(1), 39-56 (in Russ.). doi: 10.17323/727-0634-2019-17-1-39-56

Tönnies F. (2002). Obshchnost' $i$ obshchestvo: osnovnye ponjatija chistoj socilogii [Gemeinschaft und Gesellschaft. Grundbegriffe der reinen Soziologie. Russian translation]. Moscow: Vladimir Dal'.

Zakharov S.V. (Ed.) (2018). Russia's population in 2016: $24^{\text {th }}$ Annual Demographic Report. Moscow: HSE publishing house. 448 p. (In Russ.) 


\section{APPENDIX}

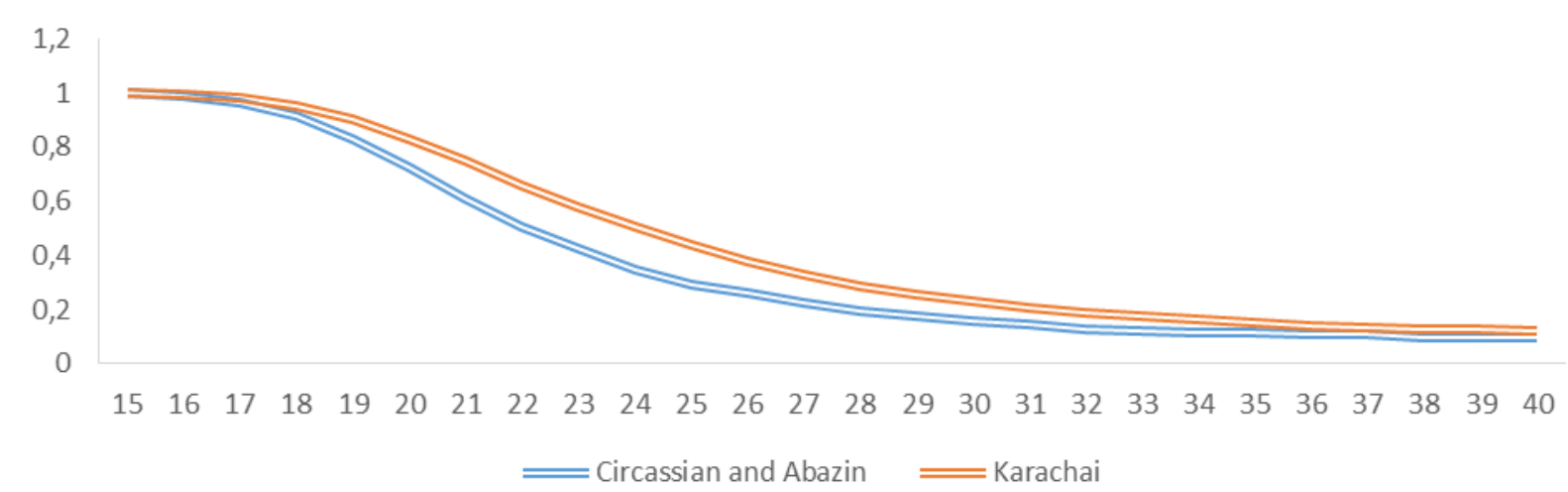

Figure A1. Cumulative probability of remaining childless, Karachai, Circassian and Abazin women born in 1950-54

Source: Data of VPN-2010.

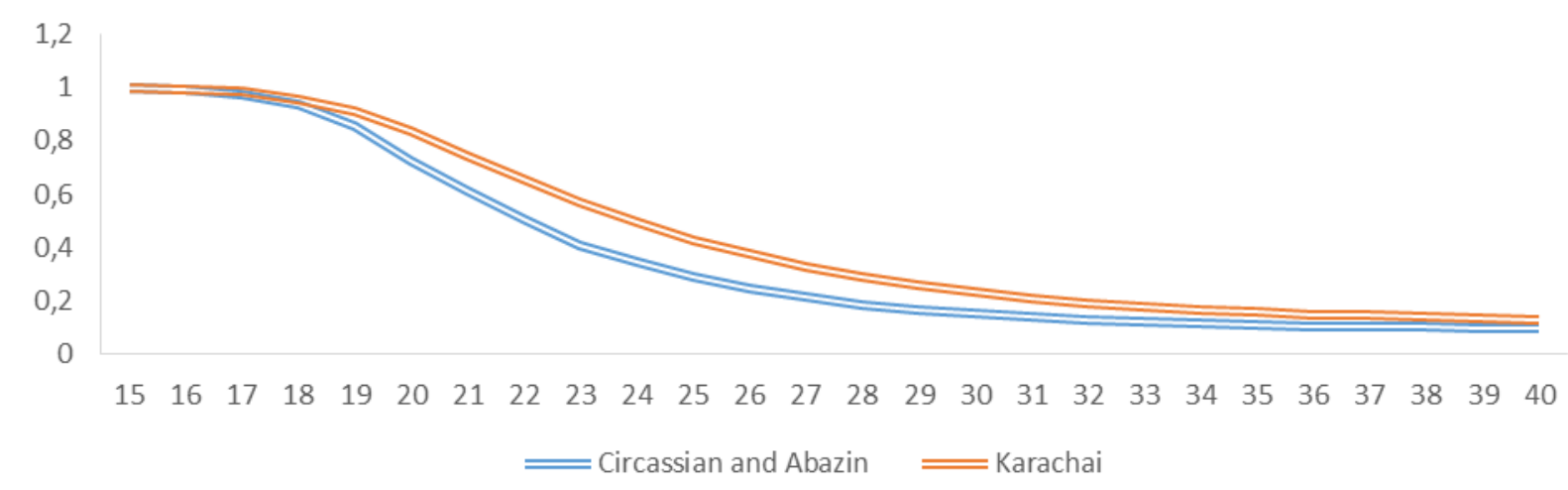

Figure A2. Cumulative probability of remaining childless, Karachai, Circassian and Abazin women born in 1955-59

Source: Data of VPN-2010.

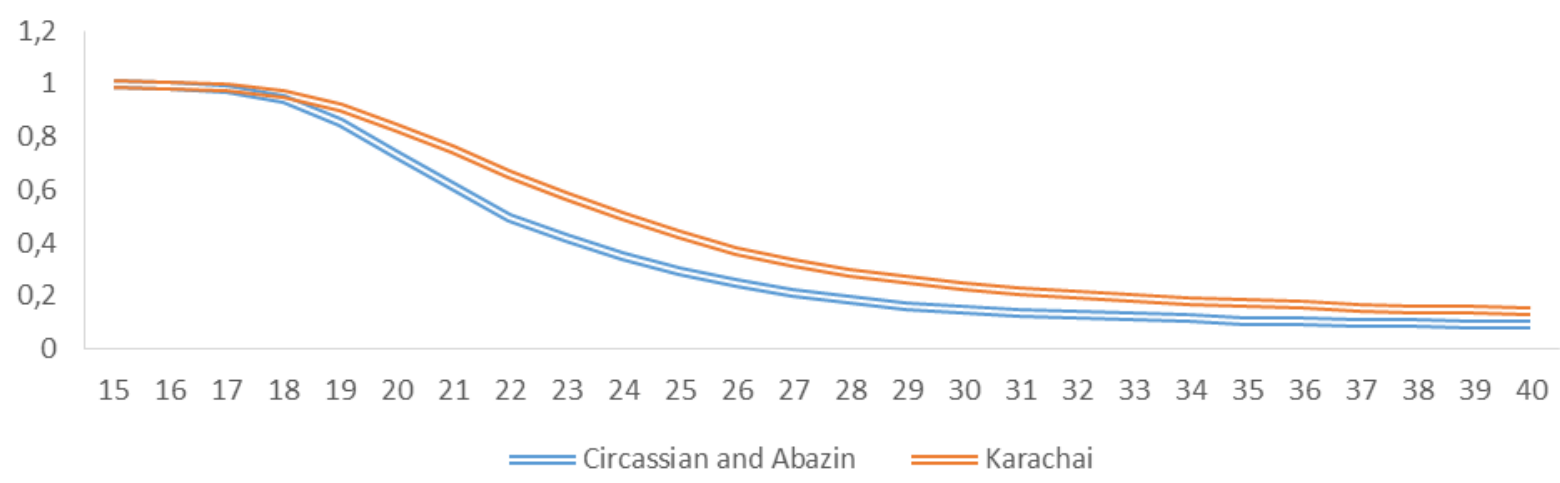

Figure A3. Cumulative probability of remaining childless, Karachai, Circassian and Abazin women born in 1960-64

Source: Data of VPN-2010. 


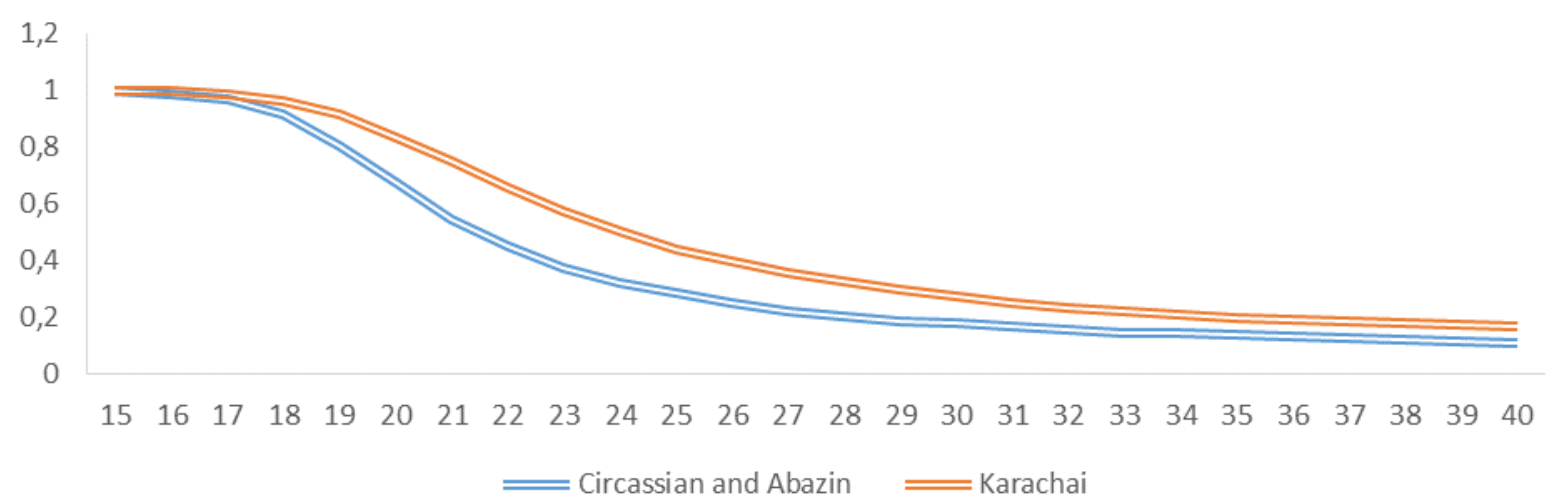

Figure A4. Cumulative probability of remaining childless, Karachai, Circassian and Abazin women born in 1965-69

Source: Data of VPN-2010.

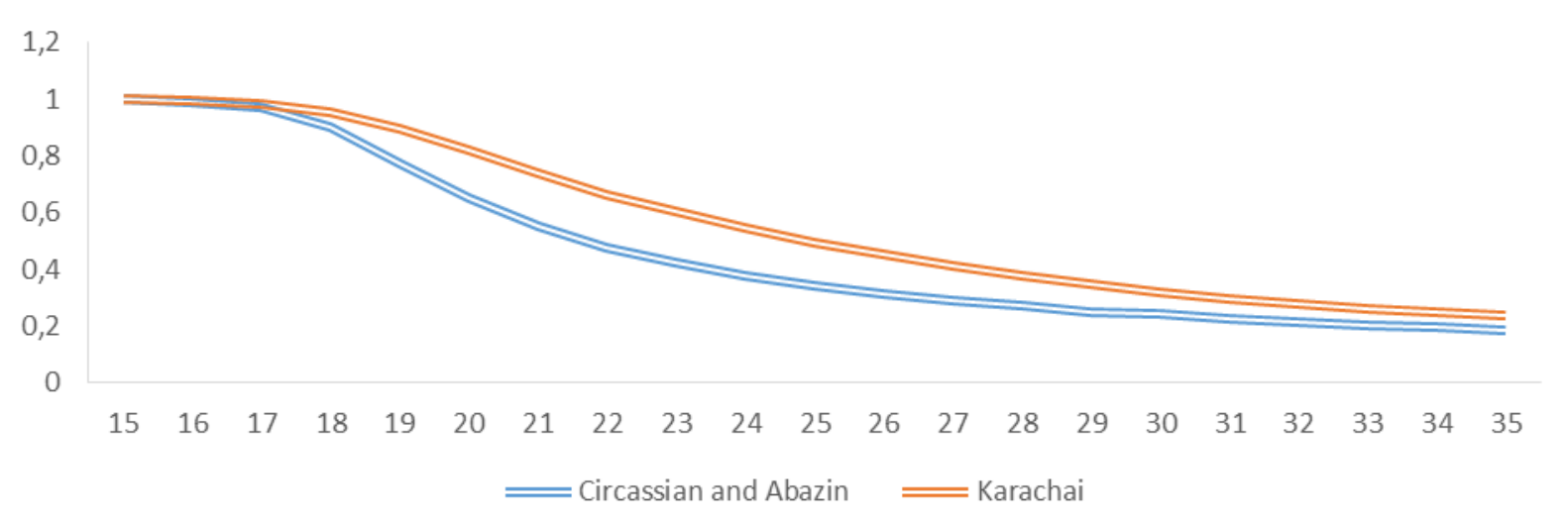

Figure A5. Cumulative probability of remaining childless, Karachai, Circassian and Abazin women born in 1970-74

Source: Data of VPN-2010.

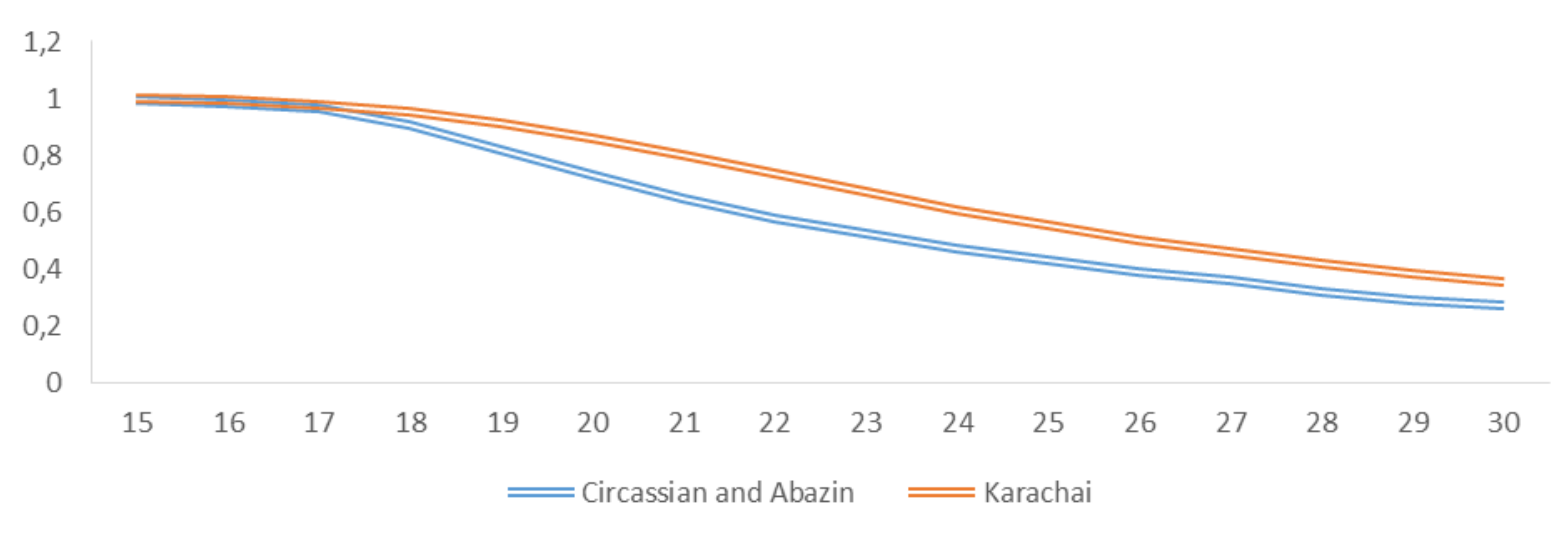

Figure A6. Cumulative probability of remaining childless, Karachai, Circassian and Abazin women born in 1975-79

Source: Data of VPN-2010. 


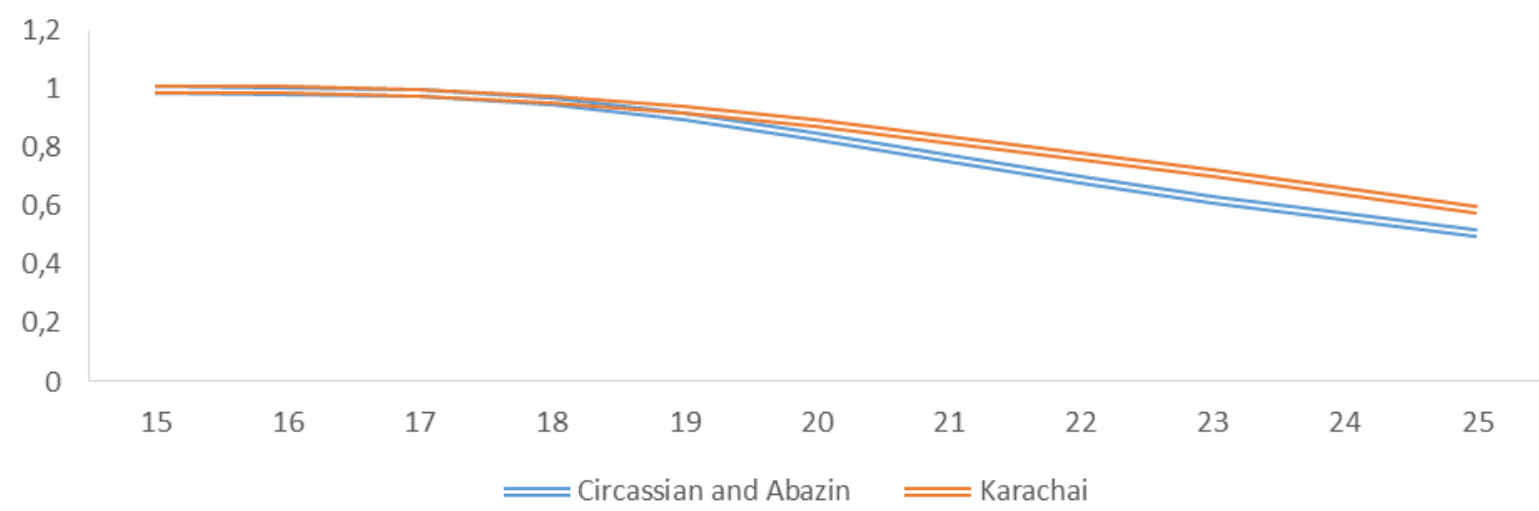

Figure A7. Cumulative probability of remaining childless, Karachai, Circassian and Abazin women born in 1980-84

Source: Data of VPN-2010. 